\title{
Analysis of Multiple Pesticides Residues in Market Samples of Okra and Associated Dietary Risk Assessment for Consumers
}

Syeda Nazish Ali

National Agricultural Research Centre https://orcid.org/0000-0002-9582-2562

Nazia Rafique

National Agricultural Research Centre

Shazia Akhtar

National Agricultural Research Centre

Touqeer Taj

National Agricultural Research Centre

Farrakh Mehboob ( farrakhmehboob@parc.gov.pk)

National Agricultural Research Centre

Research Article

Keywords: Pesticide residues, Okra, QuEChERS, LC-MS/MS, Consumer dietary risk assessment

Posted Date: October 29th, 2021

DOI: https://doi.org/10.21203/rs.3.rs-978980/v1

License: @) (7) This work is licensed under a Creative Commons Attribution 4.0 International License. Read Full License

Version of Record: A version of this preprint was published at Environmental Science and Pollution Research on February 19th, 2022. See the published version at https://doi.org/10.1007/s11356-022-19197-9. 


\begin{abstract}
European Union Reference Laboratory method for Fruits and Vegetable (EURL-FV-2010-M1) for the quantification of pesticide residues was verified for the determination of multiple pesticides residues in okra. The targeted pesticides were extracted using acetonitrile with citrate buffer salts followed by cleanup with primary secondary amine (PSA) and analyzed on LC-MS/MS. The recoveries for all the targeted pesticides were within an acceptable range of 70.1 $116.6 \%$ and precision in terms of RSD was $0.3-18.1 \%$, respectively. The limit of quantification ranged from $0.002 \mathrm{mg} / \mathrm{kg}$ for carbofuran to $0.5 \mathrm{mg} / \mathrm{kg}$ for acypermethrin. The status of pesticide residues in okra $(n=21)$ available to consumers in the main markets of Pakistan has been determined by using this verified method. Sixty-two percent of the tested samples were contaminated out of which three samples were non-compliant with European Union Maximum residue limits (EU-MRL). The pesticides violating the EU-MRL were bifenthrin, thiamethoxam, and triazophos. For all the detected pesticides, estimated daily intake (EDI) ranged between $7.39 \times 10^{-6}$ and $1.78 \times 10^{-4} \mathrm{mg} / \mathrm{kg}$ of body weight while the values of Health Index $(\mathrm{HI})$ fluctuated between $8.9 \times 10^{-5}$ and $1.8 \times 10^{-2}$. Although, residues of some pesticides were reported to be non-compliant with EU-MRLs, yet the risk posed by these pesticides to human health was insignificant.
\end{abstract}

\title{
1. Introduction
}

Vegetables are a vital source of various nutritional components like vitamins, minerals, and fibers. According to dietary guidelines, fresh vegetables are highly recommended to be included in routine diet to avoid the risk of chronic disease and to maintain a healthy life pattern (Hu et al., 2016; You, 2015). Okra (Abelmoschus esculentus L.) is a delicious and nutritious vegetable consumed directly for eating in soups and salads or cooked in different ways worldwide. It is the national vegetable of Pakistan and is one of the most important vegetable crops grown in the country (Ali et al., 2012; Sheikh et al., 2012). Pakistan is the 5 th largest producer of okra that contributes to $1.3 \%$ of the world's okra production. Pakistan is also exporting surplus okra to various countries including Afghanistan, Iran, Malaysia \& UAE (GOP, 2019).

Many pests including different species of jassids, aphids, and mites are potential threats to okra crops (Atwal \& Dhaliwal, 2015). The most problematic pests of okra are shoot and fruit borers that attack the crop at the fruiting stage (Mishra \& Singh, 1996). To cope with all these pests, different kinds of pesticides specifically acetamiprid, bifenthrin, dimethoate, imidacloprid, thiacloprid, and thiamethoxam are recommended and applied in fields to ensure the healthy growth and sound yield (Ali, 2018).

Some studies have assessed the presence of residues of different pesticides in okra. The residues of some organochlorine and organophosphate pesticides have been reported at high concentration in okra samples collected from Punjab, Pakistan using GC-ECD technique (Randhawa et al., 2016; Randhawa et al., 2015). The residues of pyrethroid pesticides in okra samples using GC- $\mu$ ECD from Punjab, Pakistan and their dietary risk have also been reported (Amjad et al., 2019). Pesticides residues in okra as a non-target crop grown close to a watermelon farm have also been reported from Ghana using GC/MS technique (Essumang et al., 2013). Another study has assessed the residues of multi-class pesticides using GC-ECD and associated health risk from dietary intake in okra from Bangladesh (Hossain et al., 2013). However, there are a few studies where state of the art and sensitive equipment like triple quad mass spectrometers have been used. One such study has assessed the residues of seventy-four pesticides in okra samples from India using the both, LC-MS/MS and GC-MS/MS techniques (Ratnamma et al., 2020). Another study has reported residues of several pesticides in okra samples from Sri Lanka using GCMS/MS technique (Pandipperuma, 2020).

Rejection of multiple okra consignments of other countries have been reported by EU-RASFF (European Union-Rapid Alert System for Food and Feed) and USFDA (United States-Food and Drug Administration) import alert systems in international export regime due to the presence of several pesticides with values higher than prescribed standards ("FDA-Import Alerts," ; "RASFF - Food and Feed Safety Alerts. European Commission.," 2020). If any country is to target these markets then it shall have reliable data on monitoring of pesticides residue in okra.

Objectives of the present study is to verify the standard method of European Union Reference Laboratory for Fruits and Vegetable (EURL-FV. 2010-M1), evaluation of the current status of pesticide residues in market samples of okra in Pakistan and determining their compliance for maximum residues limits (MRL) established by FAO Codex Alimentarius and European Union. Moreover, consumer's dietary health risk assessment of pesticide residues detected in okra were also evaluated. This study will provide a verified analytical method that can be used as a standard regulatory tool for pesticide residue testing laboratory for the routine testing of pesticides in okra, preliminary data for planned surveillance studies in the country and identify the real problematic pesticides in okra production.

\section{Methodology}

\subsection{Sample Collection and Preservation}

Five hundred grams of fresh home-grown pesticide-free okra for method verification was collected in a plastic-zipped sample bag, preserved in cold storage at $-18^{\circ} \mathrm{C}$, and brought to Pesticides Residue Testing Laboratory, NARC Islamabad. Sample The sample was then chopped and homogenized by using RetschGrindoMix at 10,000 rpm for 4 minutes. This well-homogenized sample was stored at $-18^{\circ} \mathrm{C}$ till further analysis. In total, twenty-one samples of okra from local markets of different okra producing areas of Pakistan were collected, preserved in the freezer at $-18^{\circ} \mathrm{C}$ in Aquatic and Environmental Toxicology Laboratory located in Sustainable Development Study Centre (SDSC)-Environmental Science, Government College University Lahore. The frozen samples were transported to Pesticides Residue Testing Laboratory, NARC Islamabad. These samples were then processed and preserved using the aforementioned method. Map of sampling sites was shown in electronic supplementary information (Fig.S1).

\subsection{Chemicals and Equipment}


All the selected pesticide standards were of high purity grade, purity ranging from 95 to $99.9 \%$ (except for indoxacarb with $93.9 \%$ purity). Acetonitrile (> $99 \%$ purity) was obtained from Merck (Germany); analytical grade trisodium citrate dihydrate (98\%), sodium chloride and disodium hydrogen citrate sesquihydrate (99\%) were obtained from Sigma-Aldrich (USA); magnesium sulphate (anhydrous) from DAEJUNG (Korea); PSA, ammonium formate (97\%) and formic acid (98\%) were purchased from Supelco (USA). LC-MS grade water was produced using water distillation unit (Thermo Scientific, SMART2PURE, Sweden). Other instruments used were vortex mixer (VELP, Scientifica), centrifuge (LX111HCS-LABDEX), and nitrogen air generator (NG UHP 5000X, CMC, Instruments GmbH Germany). Stock solutions of selected pesticides were prepared in acetonitrile

\subsection{Pesticide Selection and Mixture Preparation}

Targeted pesticides for method validation were selected based on being recommended for okra crop and rejections reported by EU-RASFF and FDA import alerts systems. Maximum residual limits (MRLs) of selected pesticides from different okra importing and exporting countries were compared. As EU-MRLs were more stringent for most of the selected pesticides so they were selected as a reference for the present study (Table S1). The mixture of all these selected pesticides was prepared in acetonitrile by evaporating the other solvents by using the gentle stream of nitrogen. A series of calibration standards and matrixmatched standards of different concentrations ranging from 5 to $0.005 \mathrm{mg} / \mathrm{ml}$ were prepared for the quantification of targeted pesticides.

\subsection{Sample Preparation (Extraction \& Cleanup)}

The citrate buffered QuEChERS method with PSA clean-up used by European Union reference laboratories (EURL) (EURL-FV. 2010-M1) was used for the extraction of the selected pesticides from okra samples. To validate the method for selected pesticides in okra, samples were spiked at three different fortification levels with three replicates regarding pesticides' MRL values set by EU (Table S2). Briefly, in $10 \mathrm{~g}$ of blended and well-homogenized okra sample, $10 \mathrm{ml}$ acetonitrile was added, vortex for one minute followed by the addition of $4 \mathrm{~g}$ magnesium sulfate anhydrous for retaining the moisture, $1 \mathrm{~g}$ sodium chloride for better phase separation, $1 \mathrm{~g}$ trisodium citrate dehydrate, and $0.5 \mathrm{~g}$ disodium hydrogencitrate sesquihydrate for $\mathrm{pH}$ stabilization. Samples were then vortexed for $1 \mathrm{~min}$ and centrifuged for 5 minutes at $4000 \mathrm{rpm}$. A layer of $6 \mathrm{ml}$ aliquot was transferred to a $15 \mathrm{ml}$ falcon tube containing $900 \mathrm{mg}$ of magnesium sulfate anhydrous and $150 \mathrm{mg}$ of primary secondary amine (PSA) for clean-up of extracts. Samples were then again vortexed for 1 minute and centrifuged at $4000 \mathrm{rpm}$ for 5 minutes. $1 \mathrm{ml}$ from this extract was filtered through PTFE 0.2 micron syringe filters in $1.5 \mathrm{ml}$ vials and proceeded to analysis (EURL-FV, 2010). For method validation studies, $10 \mathrm{~g}$ of blended and homogenized okra sample was spiked, vortexed for complete mixing, and left overnight to allow a uniform distribution of pesticides.

\subsection{Instrumental Analysis}

Analysis of targeted pesticides in okra was done using LC-MS/MS (Agilent technologies 1290 Infinity-II LC coupled with 6420 triple Quadrupole Mass Spectrometer). Thermo Quest Hypersil BDS C18 $(4.6 \times 150 \mathrm{~mm}, 5 \mu \mathrm{m})$ column at $40^{\circ} \mathrm{C}$ was used for the pesticides quantification. Two different combinations of the mobile phase were used to find the best suitable mobile phase for optimum recovery of targeted pesticides. These combinations included deionized water buffered with $0.1 \%$ formic acid and $5 \mathrm{mM}$ ammonium formate as a fixed-mobile phase with non-buffered acetonitrile or acetonitrile buffered with $0.1 \%$ formic acid and $5 \mathrm{mM}$ ammonium formate. The mobile flow rate was adjusted at $0.8 \mathrm{ml}$ per minute run in the time-gradient mode for a 16 minutes cycle. The ratio of mobile phase (water to acetonitrile) was at 80:20 for the first 2 minutes that changed to 65:35 for the next 6 minutes, reaching 5:95 for the next 6 minutes, and finally again on 80:20 in the last 2 minutes of the cycle. The injection volume was 5 ul.

The details of MS parameters (precursor and two product ions, Fragmentor voltage, cell acceleration voltage (eV), and collision energy (V) are given in Table 1. At the ion source, the gas temperature was kept at $325^{\circ} \mathrm{C}$ with a flow of $12 \mathrm{~L} / \mathrm{min}$ and the pressure of the nebulizer was 35 psi. Capillary voltage for positive and negative polarity was 3500 and 3000 V, respectively. Mass Hunter Data Acquisition, Qualitative Analysis, and Quantitative Analysis softwares (Agilent Technologies, Palo Alto, CA, v.B.02) were used for data acquisition and the method validation. Microsoft Excel 2013 was used for the analysis of data. 
Table 1

LC-MS/MS method acquisition parameters for targeted pesticides analysis in Okra

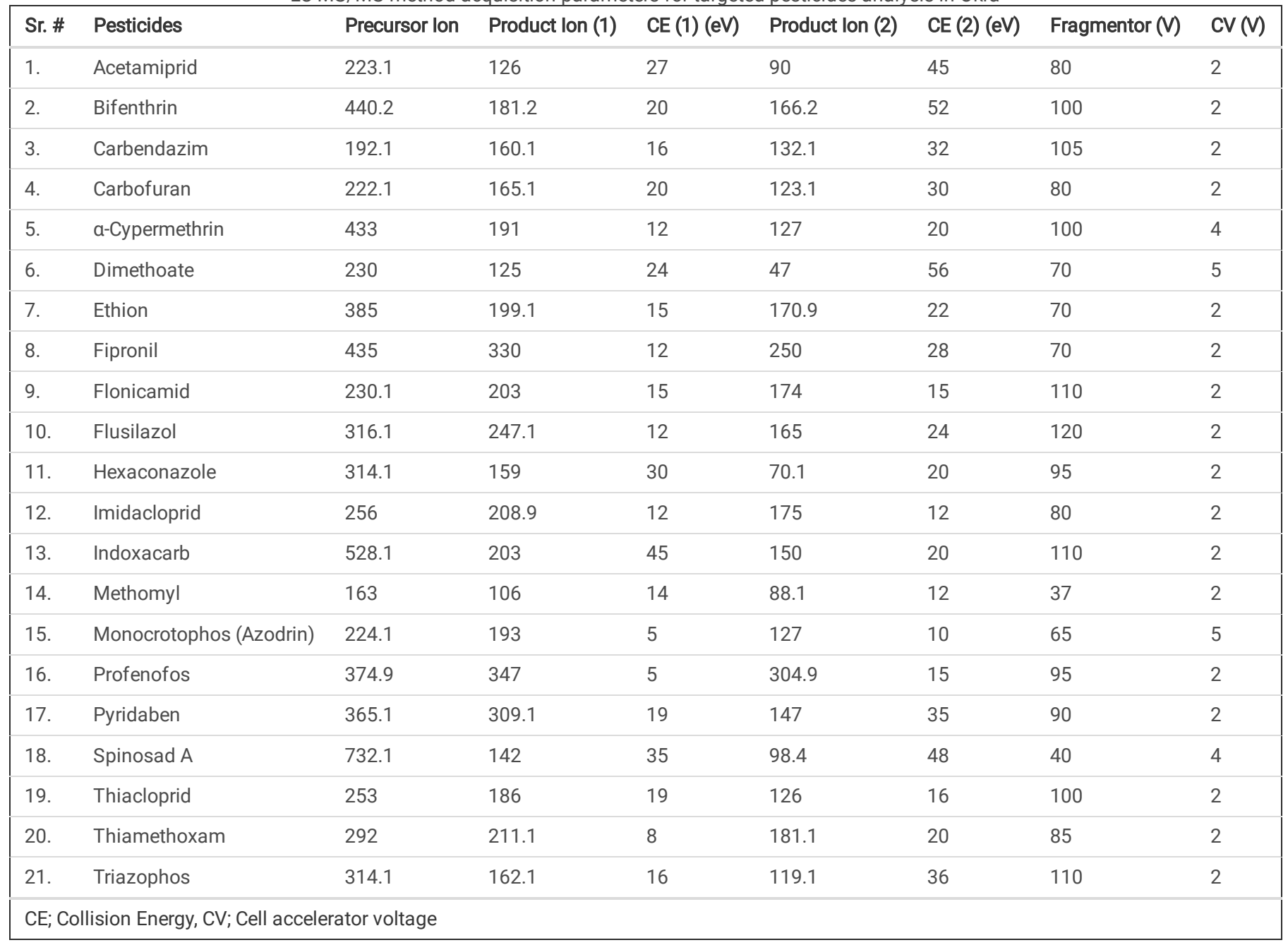

\subsection{Quality Control and Quality Assessment}

To ensure the quality control, calibration standards and matrix matched standards of different concentrations relative to spiked concentration of pesticides were run with each batch. Effect of matrix on targeted pesticides was calculated as percentage matrix effect by comparing the slope of pesticides in solvent standards against the slope in matrix matched standards. Intra-lab method repeatability was assessed by repeating the whole method from extraction to analysis after twenty-five days on same fortification levels as of previous analysis to ensure the validity of method. Method accuracy and precision were also compared with the reference method. Acceptability criteria for the positive identification in real samples was set as RT drift between the tested sample and MMS of organic okra less than \pm 0.1 , and difference of qualifier to quantifier ion ratio in tested sample and mean ratio of matrix matched standard analyzed in same batch was less than $30 \%$..

Estimation of measurement uncertainty for the validated method was determined. All the potential sources of uncertainty in chemical/ physical measurements were identified and enlisted. Standard uncertainty of each component was calculated either by using type A uncertainty calculation by statistical methods or Type B from certificates of calibrated equipment. The standard uncertainties were combined by Roots of Sum Square (RSS) rule. Expanded uncertainty (U \%) at 95\% confidence interval was calculated by multiplying combine uncertainty with k factor (Ellison \& Williams, 2012).

\subsection{Health Risk Assessment}

Consumer health risk related with pesticide residues was assessed by using the method reported by Ratnamma et al. (Ratnamma et al., 2020). Following formula was used to calculate the estimated daily intake (EDI):

$E D I=\frac{C \times C R}{B W}$

Where, $\mathrm{C}$ is the concentration of pesticide residue in the sample, $\mathrm{CR}$ is per capita consumption rate of okra. The value for per capita consumption of okra by Pakistani population was considered as $57.77 \mathrm{~g} / \mathrm{d}$ (Arifullah et al., 2008) and average body weight (BW) of an adult that was taken as $62.5 \mathrm{~kg}$ (WHO, 2016).

Hazard Index (HI) was then calculated by: 
$H I=\frac{E D I}{A D I}$

Where ADI is the acceptable daily intake (Turner, 2018).

\section{Results \& Discussion}

\subsection{Validation of Selected Analytical Method}

\subsubsection{Method Linearity}

The method was validated for the analysis of residues of twenty-one pesticides in okra. The value of regression coefficient $\left(R^{2}\right)$ were greater than 0.99 for both i.e. solvent standards and matrix matched standards for all selected pesticides (Table S3). Analytical method was linear from 0.002 to $1 \mathrm{mg} / \mathrm{kg}$.

\subsubsection{Method Accuracy and Precision and Comparison with Reference Method}

Mean recoveries of spiked samples $(n=3)$ were within acceptable range of 70-120\% for all selected pesticides, except for ethion, indoxacarb, and methomyl. For ethion and indoxacarb, the value of percentage recovery was slightly deviating from that of the acceptable range i.e. $128.57 \% \& 62.12 \%$, respectively at lowest fortification level i.e. level 1. For methomyl, percentage recovery was below the acceptable range at all fortification levels (Table 2).

Table 2: Reproducibility of method for pesticides in Okra

\begin{tabular}{|c|c|c|c|c|c|c|c|c|c|c|c|c|c|}
\hline \multirow[t]{3}{*}{ Sr. \# } & \multirow[t]{3}{*}{ Pesticides } & \multicolumn{6}{|c|}{ Intra-Day Recovery } & \multicolumn{6}{|c|}{ Inter-Day Recovery } \\
\hline & & \multicolumn{2}{|l|}{ Level 1} & \multicolumn{2}{|l|}{ Level 2} & \multicolumn{2}{|l|}{ Level 3} & \multicolumn{2}{|l|}{ Level 1} & \multicolumn{2}{|l|}{ Level 2} & \multicolumn{2}{|l|}{ Level 3} \\
\hline & & $\begin{array}{l}\text { Mean } \\
\text { Recovery }\end{array}$ & $\begin{array}{l}\text { RSD } \\
\%\end{array}$ & $\begin{array}{l}\text { Mean } \\
\text { Recovery }\end{array}$ & $\begin{array}{l}\text { RSD } \\
\%\end{array}$ & $\begin{array}{l}\text { Mean } \\
\text { Recovery }\end{array}$ & $\begin{array}{l}\text { RSD } \\
\%\end{array}$ & $\begin{array}{l}\text { Mean } \\
\text { Recovery }\end{array}$ & $\begin{array}{l}\text { RSD } \\
\%\end{array}$ & $\begin{array}{l}\text { Mean } \\
\text { Recovery }\end{array}$ & $\begin{array}{l}\text { RSD } \\
\%\end{array}$ & $\begin{array}{l}\text { Mean } \\
\text { Recovery }\end{array}$ & $\begin{array}{l}\text { RSD } \\
\%\end{array}$ \\
\hline 1 & Acetamiprid & 79.36 & 2.30 & 87.99 & 2.82 & 90.61 & 1.72 & 93.40 & 1.96 & 84.87 & 0.30 & 78.27 & 0.83 \\
\hline 2 & Bifenthrin & 116.28 & 14.27 & 104.73 & 1.54 & 99.72 & 14.89 & 76.03 & 12.33 & 115.63 & 4.49 & 77.77 & 4.19 \\
\hline 3 & Carbendazim & 72.65 & 3.85 & 74.15 & 4.67 & 80.97 & 2.60 & 96.30 & 2.25 & 81.87 & 7.02 & 72.73 & 3.38 \\
\hline 4 & Carbofuran & 76.02 & 5.38 & 85.23 & 8.00 & 94.36 & 5.66 & 101.90 & 15.72 & 95.87 & 6.57 & 81.40 & 3.52 \\
\hline 5 & a-Cypermethrin & 75.17 & 10.50 & 81.55 & 4.92 & 71.57 & 6.22 & 66.13 & 14.28 & 113.47 & 5.99 & 73.03 & 1.48 \\
\hline 6 & Dimethoate & 95.16 & 11.43 & 82.87 & 7.35 & 81.87 & 3.50 & 99.09 & 15.54 & 80.32 & 6.52 & 80.43 & 9.09 \\
\hline 7 & Ethion & 128.57 & 36.86 & 70.57 & 4.98 & 61.00 & 5.68 & 72.33 & 10.43 & 81.15 & 24.31 & 75.60 & 0.26 \\
\hline 8 & Fipronil & 99.76 & 16.18 & 87.36 & 13.81 & 80.30 & 6.33 & 71.20 & 2.18 & 88.30 & 2.72 & 84.23 & 5.73 \\
\hline 9 & Flonicamid & 104.27 & 18.11 & 109.39 & 10.07 & 93.11 & 5.00 & 71.65 & 1.71 & 88.59 & 33.54 & 83.07 & 4.31 \\
\hline 10 & Flusilazol & 97.67 & 4.94 & 97.02 & 9.18 & 82.18 & 1.47 & 96.33 & 3.18 & 85.27 & 15.07 & 78.33 & 2.32 \\
\hline 11 & Hexaconazole & 85.42 & 17.35 & 86.70 & 17.79 & 94.99 & 1.28 & 75.43 & 14.94 & 116.59 & 15.15 & 80.10 & 8.38 \\
\hline 12 & Imidacloprid & 70.30 & 1.39 & 91.47 & 2.92 & 97.74 & 2.81 & 85.40 & 4.21 & 82.97 & 8.74 & 82.10 & 4.17 \\
\hline 13 & Indoxacarb & 62.12 & 14.91 & 73.92 & 16.01 & 100.66 & 2.46 & 72.29 & 6.67 & 108.17 & 16.06 & 77.47 & 3.23 \\
\hline 14 & Methomyl & 51.57 & 32.32 & 62.11 & 4.16 & 69.59 & 16.63 & 72.0 & 17.80 & 72.73 & 12.21 & 79.53 & 2.86 \\
\hline 15 & Monocrotophos & 76.21 & 8.78 & 70.09 & 16.41 & 87.27 & 8.02 & 90.13 & 11.28 & 80.20 & 10.11 & 82.87 & 6.83 \\
\hline 16 & Profenofos & 88.60 & 8.40 & 70.47 & 5.20 & 67.65 & 3.89 & 89.77 & 6.29 & 67.13 & 15.57 & 78.10 & 6.48 \\
\hline 17 & Pyridaben & 90.90 & 12.55 & 80.50 & 4.11 & 70.26 & 3.71 & 72.07 & 12.06 & 72.73 & 29.30 & 78.90 & 4.17 \\
\hline 18 & Spinosade & 76.21 & 8.78 & 85.72 & 2.90 & 85.68 & 3.18 & 102.80 & 4.04 & 78.37 & 9.99 & 72.80 & 8.45 \\
\hline 19 & Thiacloprid & 92.02 & 3.72 & 90.76 & 2.66 & 89.01 & 3.42 & 92.93 & 4.04 & 82.13 & 8.58 & 77.00 & 6.46 \\
\hline 20 & Thiamethoxam & 113.11 & 5.92 & 107.51 & 6.23 & 87.62 & 5.09 & 86.45 & 15.46 & 80.33 & 7.12 & 76.97 & 6.14 \\
\hline 21 & Triazophos & 81.67 & 7.34 & 85.22 & 9.86 & 99.14 & 3.48 & 80.17 & 2.59 & 76.33 & 11.54 & 80.93 & 2.79 \\
\hline
\end{tabular}

Method accuracy and precision of current validated method were compared with reference method (EURL-FV. 2010-M1). The reference method was validated at concentrations ranging from 0.01 to $0.1 \mathrm{mg} / \mathrm{kg}$. The current method has used EU-MRLs as a baseline criteria and spiked concentrations of pesticides were relevant to their EU-MRLs. The current method has been successfully validated for carbofuran, dimethoate, fipronil, flusilazol, hexaconazole, monocrotophos, profenofos, pyridaben, thiacloprid, thiamethoxam and triazophos at concentrations below than those reported in reference method (Table 3). For methomyl and spinosad, the method was validated on the same concentrations as were reported by reference method (Table 3). 
Table 3

Comparison of current method with reference method in terms of validated concentrations

\begin{tabular}{|c|c|c|c|c|}
\hline $\begin{array}{l}\text { Sr. } \\
\#\end{array}$ & Pesticides & $\begin{array}{l}\text { Concentration at which the reference } \\
\text { method validated } \\
\text { (mg/kg) } \\
\text { (EURL-FV-2010-M1) }\end{array}$ & $\begin{array}{l}\text { Concentration at which the current method } \\
\text { validated\& verified } \\
(\mathrm{mg} / \mathrm{kg})\end{array}$ & $\begin{array}{l}\text { Method Comparison in terms of } \\
\text { concentration }\end{array}$ \\
\hline 1. & Acetamiprid & 0.01 & 0.05 & above \\
\hline 2. & Bifenthrin & 0.01 & 0.1 & above \\
\hline 3. & Carbendazim & 0.01 & 0.025 & above \\
\hline 4. & Carbofuran & 0.01 & 0.002 & below \\
\hline 5. & a-Cypermethrin & 0.01 & 0.5 & above \\
\hline 6. & Dimethoate & 0.01 & 0.005 & below \\
\hline 7. & Ethion & 0.01 & 0.01 & above \\
\hline 8. & Fipronil & 0.01 & 0.0025 & below \\
\hline 9. & Flonicamid & 0.01 & 0.03 & above \\
\hline 10. & Flusilazol & 0.01 & 0.005 & below \\
\hline 11. & Hexaconazole & 0.01 & 0.005 & below \\
\hline 12. & Imidacloprid & 0.01 & 0.25 & above \\
\hline 13. & Indoxacarb & 0.01 & 0.02 & above \\
\hline 14. & Methomyl & 0.01 & 0.01 & equivalent \\
\hline 15. & Monocrotophos & 0.01 & 0.005 & below \\
\hline 16. & Profenofos & 0.01 & 0.005 & below \\
\hline 17. & Pyridaben & 0.01 & 0.005 & below \\
\hline 18. & Spinosade & 0.01 & 0.01 & equivalent \\
\hline 19. & Thiacloprid & 0.01 & 0.005 & below \\
\hline 20. & Thiamethoxam & 0.01 & 0.005 & below \\
\hline 21. & Triazophos & 0.01 & 0.005 & below \\
\hline
\end{tabular}

\subsection{Method Sensitivity}

The limits of detection with the validated method ranged from $0.001 \mathrm{mg} / \mathrm{kg}$ for carbofuran to $0.25 \mathrm{mg} / \mathrm{kg}$ for a-cypermethrin while the limits of quantification ranged from $0.002 \mathrm{mg} / \mathrm{kg}$ for carbofuran to $0.5 \mathrm{mg} / \mathrm{kg}$ for a-cypermethrin (Table 4). 
Table 4

Limits of Detection (LODs), Limits of Quantification (LOQs) and Measurement Uncertainty (\%)

\begin{tabular}{|c|c|c|c|c|c|c|c|}
\hline \multirow[t]{2}{*}{ Sr. \# } & \multirow[t]{2}{*}{ Compound Name } & \multirow{2}{*}{$\begin{array}{l}\text { EU MRL } \\
(\mathrm{mg} / \mathrm{kg})\end{array}$} & \multirow{2}{*}{$\begin{array}{l}\text { LODs } \\
(\mathrm{mg} / \mathrm{kg})\end{array}$} & \multirow{2}{*}{$\begin{array}{l}\text { LOQs } \\
\text { (mg/kg) }\end{array}$} & \multicolumn{3}{|c|}{ Measurement Uncertainty (\% } \\
\hline & & & & & Level 1 & Level 2 & Level 3 \\
\hline 1. & Acetamiprid & 0.2 & 0.025 & 0.05 & 20.4 & 12.3 & 8.2 \\
\hline 2. & Bifenthrin & 0.2 & 0.05 & 0.1 & 24.5 & 9.2 & 24.2 \\
\hline 3. & Carbendazim & 2 & 0.01 & 0.025 & 35.6 & 20.4 & 13.2 \\
\hline 4. & Carbofuran & 0.002 & 0.001 & 0.002 & 30.1 & 31.7 & 29.0 \\
\hline 5. & a-Cypermethrin & 0.5 & 0.1 & 0.5 & 22.7 & 18.7 & 11.9 \\
\hline 6. & Dimethoate & 0.01 & 0.001 & 0.005 & 46.7 & 32.3 & 25.3 \\
\hline 7. & Ethion & 0.01 & 0.0025 & 0.01 & 71.5 & 45.5 & 30.4 \\
\hline 8. & Fipronil & 0.005 & 0.00125 & 0.0025 & 46.1 & 39.0 & 27.0 \\
\hline 9. & Flonicamid & 0.03 & 0.0075 & 0.03 & 63.1 & 28.3 & 13.4 \\
\hline 10. & Flusilazol & 0.01 & 0.001 & 0.005 & 21.9 & 21.9 & 13.9 \\
\hline 11. & Hexaconazole & 0.01 & 0.001 & 0.005 & 42.3 & 41.4 & 14.0 \\
\hline 12. & Imidacloprid & 0.5 & 0.025 & 0.25 & 16.4 & 10.6 & 8.5 \\
\hline 13. & Indoxacarb & 0.02 & 0.01 & 0.02 & 103.6 & 53.5 & 11.9 \\
\hline 14. & Methomyl & 0.01 & 0.001 & 0.01 & 67.1 & 30.0 & 35.6 \\
\hline 15. & Monocrotophos & 0.01 & 0.001 & 0.005 & 37.5 & 35.2 & 27.7 \\
\hline 16. & Profenofos & 0.01 & 0.001 & 0.005 & 25.0 & 18.7 & 15.2 \\
\hline 17. & Pyridaben & 0.01 & 0.001 & 0.005 & 17.5 & 18.2 & 12.7 \\
\hline 18. & Spinosad & 0.02 & 0.005 & 0.01 & 29.4 & 13.4 & 10.3 \\
\hline 19. & Thiacloprid & 0.01 & 0.001 & 0.005 & 21.2 & 16.1 & 14.9 \\
\hline 20. & Thiamethoxam & 0.01 & 0.001 & 0.005 & 41.1 & 23.3 & 16.0 \\
\hline 21. & Triazophos & 0.01 & 0.001 & 0.005 & 25.8 & 22.2 & 14.7 \\
\hline
\end{tabular}

\subsubsection{Matrix Effect}

The matrix effect for all pesticides was insignificant $(< \pm 20 \%)$ except for a few of the following pesticides a slight signal suppression was observed i.e. bifenthrin (-24.85\%), carbendazim (-21.10\%), flusilazol (-21.31\%), hexaconazole (-22.44\%), and methomyl (-26.70\%) (Fig. 1).

\subsubsection{Intra and Inter-day Reproducibility}

The validated method was repeated from extraction of samples to instrumental analysis following the exact parameters of previous analysis after twenty-five days. Percentage recoveries of targeted pesticides were again calculated and then compared with the recoveries of previous analysis. Results were consistent for all pesticides except for ethion, indoxacarb and methomyl, for which the slight deviations from previous analysis were observed (Table 2). Slight variation in method reproducibility for these pesticides might be due to ion suppression which is very common in case of LC-MS/MS (Furey et al., 2013).

\subsection{Measurement Uncertainty}

Expanded uncertainty ( $\mathrm{U} \%)$ for all the three fortification levels are tabulated in Table 4 . U\% is within an acceptable range of $50 \%$ for all pesticides except for ethion, flonicamid, and methomyl at lowest fortification level and for indoxacarb at fortification lowest and medium fortification level (Table 4). For ethion and methomyl, the major contributing factor to higher value of measurement uncertainty were fluctuating values of percentage recovery at fortification level 1 . For flonicamid \& indoxacrb, it was due to higher value of slope of matrix matched standards which may be due to the presence of co-eluting matrix components. For indoxacarb, another reason for higher measurement uncertainty value is the low purity of its pesticide standards (93.9\%). Above results verify the feasibility of the validated method for routine testing of the selected pesticides in okra.

\subsection{Status of pesticide residues in market samples of okra}

Thirteen out of twenty-one samples were contaminated with five different pesticides, out of which three samples were found to be non-complaint with EUMRLs (Table 5). The frequently detected pesticides were triazophos and thiamethoxam, while the pesticides exceeding the EU-MRLs were bifenthrin, triazophos and thiamethoxam (Table 5). Previously, the residues of carbendazim, bifenthrin, and trizophos have been found in market samples of okra among which residues of bifenthrin and triazophos were in higher concentrations (Ratnamma et al., 2020). 
Table 5

Pesticides detected in market samples of Okra

\begin{tabular}{|lllllll|}
\hline Sr. \# & Pesticide Compound Name & EU MRL & $\begin{array}{l}\text { Frequency } \\
\text { (detected) }\end{array}$ & Range & Median & Frequency of non-compliance with EU MRLs \\
\hline 1. & Acetamiprid & 0.2 & 1 & 0.02 & 0.02 & 0 \\
\hline 2. & Bifenthrin & 0.2 & 1 & 0.2 & 0.2 & 1 \\
\hline 3. & Carbendazim & 2 & 2 & $0.004-0.06$ & 0.03 & 0 \\
\hline 4. & Thiamethoxam & 0.01 & 4 & $0.003-0.02$ & 0.007 & 1 \\
\hline 5. & Triazophos & 0.01 & 6 & $0.001-0.06$ & 0.002 & 1 \\
\hline
\end{tabular}

The residues of these pesticides in higher concentrations are possibly due to their higher application frequencies (for bifenthrin and acetamiprid, it was used twice per season), application of these pesticides at later stages of growth i.e. fruiting stage (bifenthrin and triazophos) for controlling shoot and fruit borers (a major pest of okra crop) and non-observance of recommended pre- and post-harvest intervals (Meenambigai et al., 2017; Randhawa et al., 2015).

\subsection{Health Risk Assessment}

Health risk assessment based on calculated mean residual levels of pesticides in okra samples showed minor risk to human health from pesticides as the value of $\mathrm{HI}$ for all pesticides was less than 1 . Although, residues of some pesticides were reported to be non-compliant with EU-MRLs (Table -5), yet the risk posed by these pesticides to human health was insignificant. The highest value of estimated daily intake among these pesticides was that of bifenthrin $\left(1.78 \times 10^{-4} \mathrm{mg} / \mathrm{kg}\right.$ b.w) but its hazard index was much less than $1\left(1.8 \times 10^{-2}\right)$. For all detected pesticides, values of EDI ranged from $7.39 \times 10^{-6}$ and $1.78 \times 10^{-4}$ $\mathrm{mg} / \mathrm{kg}$ of body weight while the values of Health Index (HI) fluctuated between $8.9 \times 10^{-5}$ and $1.8 \times 10^{-2}$. (Table 6).

Table 6

Assessment of consumer dietary health risk

\begin{tabular}{|lllll|}
\hline $\begin{array}{l}\text { Pesticides } \\
\text { (Detected in Samples) }\end{array}$ & $\begin{array}{l}\text { Residue Level } \\
(\mathbf{m g} / \mathbf{k g})\end{array}$ & $\begin{array}{l}\text { EDI } \\
\mathbf{( m g / k g ~ b . w )}\end{array}$ & $\begin{array}{l}\text { ADI } \\
(\mathbf{m g} / \mathbf{k g ~ b} . \mathbf{w} / \mathrm{d})\end{array}$ & \\
\hline Acetamiprid & 0.0200 & $1.85 \times 10^{-5}$ & 0.07 & $2.6 \times 10^{-4}$ \\
\hline Bifenthrin & 0.2000 & $1.85 \times 10^{-4}$ & 0.01 & $1.8 \times 10^{-2}$ \\
\hline Carbendazim (Azole) & 0.0300 & $2.77 \times 10^{-5}$ & 0.03 & $8.9 \times 10^{-4}$ \\
\hline Thiamethoxam & 0.0080 & $7.39 \times 10^{-6}$ & 0.08 & $8.9 \times 10^{-5}$ \\
\hline Triazophos & 0.0100 & $9.24 \times 10^{-6}$ & 0.001 & $8.9 \times 10^{-3}$ \\
\hline EDI; estimated daily intake, ADl; acceptable daily intake, HI; hazard index & \\
\hline
\end{tabular}

Previously, the residues of bifenthrin in okra samples from Pakistan were found to be significant and non-compliant with the standard MRLs, yet the health risk was found to be insignificant which is consistent with the results of present study (Amjad et al., 2019). The results of another study from India reported possible health risk as hazard index ranging from 0.01 to 0.03 for bifenthrin, 0.10 to 0.12 for carbendazim and 0.03 for carbofuran (Ratnamma et al., 2020 ). The health risk posed by these pesticides were also non-significant as reported in the present study.

\section{Conclusion}

European Union Reference Laboratory- Fruits and Vegetable (EURL-FV-2010-M1) method was verified for simultaneous analysis of residues of twenty-one multi-class pesticides compounds in okra. The percentage recoveries of validated method ranged from $70.1-116.6 \%$. Application of method was assured by analyzing market samples of okra collected from different areas of Pakistan. Sixty-two percent of these tested samples were contaminated out of which three samples were non-compliant with European Union Maximum residue limits (EU-MRL). The pesticides violating the EU-MRL were bifenthrin, thiamethoxam, and triazophos. In a nutshell, the proposed method is useful and reliable for the analysis of the selected pesticides in okra.

\section{Declarations}

\section{Funding}

This research work was funded by the Government of Pakistan under the PSDP project (PSDP-714) entitled "National Pesticides Residue Monitoring System in Pakistan (NPRMS)".

Acknowledgement(s) 
We acknowledge Dr. Mujtaba Baqar, Aquatic and Environmental Toxicology Lab, Sustainable Development Study Centre (SDSC)-Environmental Science, Government College University Lahore for supporting in sample collection procedure.

\section{Ethics approval and consent to participate}

Not applicable

\section{Consent for publication}

Not applicable

\section{Availability of data and materials}

Not applicable

\section{Conflicts of Interest}

On behalf of all authors, the corresponding author states that there are no financial or proprietary or competing interests in any material discussed in this article.

\section{Authors Contributions}

Conceptualization of study by FM, SNA; Method design, optimization and validation by SNA \& NR; Instrumentation, Data analysis \& Interpretation by SNA, SA, \& TT; Writing - Original Draft by SNA, Writing - Review \& Editing by NR \& FM; Project administration \& Funding by FM

\section{References}

1. Ali DMA (2018) A Hand Book for Agriculture Extension Agents on the Pesticides Registered with Recommendations for Safe Handling and Use in Pakistan. Pakistan Agricultural Research Council Ministry of National Food Security and Research, Islamabad

2. Ali MI, Khan MA, Rashid A, Javed MT, Sajid M (2012) Epidemiology of Okra Yellow Vein Mosaic Virus (OYVMV) and its management through tracer, mycotal and imidacloprid. American Journal of Plant Sciences 3(12):1741-1745

3. Amjad A, Randhawa MA, Javed MS, Muhammad Z, Ashraf M, Ahmad Z, Murtaza S (2019) Dietary intake assessment of pyrethroid residues from okra and eggplant grown in peri-urban areas of Punjab, Pakistan. Environ Sci Pollut Res 27(32):39693-39701

4. Arifullah SA, Yasmaeen G, Zulfiqar M, Chishti AF (2008) Food consumption, calorie intake and poverty status a case study of north west frontier province. Sarhad Journal of Agriculture 24(3):505-509

5. Atwal A, Dhaliwal G (2015) Agricultural pests of South Asia and their management. Kalyani Publishers

6. Ellison SL, Williams A (2012) Quantifying uncertainty in analytical measurement. 3rd Edition EURACHEM/CITAG Guide CG4, Eurachem. ISBN: 978-0-948926-30-3

7. Essumang D, Asare E, Dodoo D (2013) Pesticides residues in okra (non-target crop) grown close to a watermelon farm in Ghana. Environ Monit Assess 185(9):7617-7625

8. EURL-FV (2010) Multiresidue Method using QuEChERS followed by GC-QqQ/MS/MS and LC-QqQ/MS/MS for Fruits and Vegetable. from https://www.eurl-pesticides.eu/library/docs/fv/CRLFV_Multiresidue_methods.pdf

9. FDA-Import Alerts. Retrieved 05/11, 2020/,from https://www.accessdata.fda.gov/cms_ia/industry_25.html

10. Furey A, Moriarty M, Bane V, Kinsella B, Lehane M (2013) lon suppression; a critical review on causes, evaluation, prevention and applications. Talanta $115: 104-122$

11. GOP (2019) Government of Pakistan, Agricultural statistics of Pakistan, (2017-18). Retrieved from http://www.mnfsr.gov.pk/frmDetails.aspx

12. Hossain M, Rahman M, Islam M, Adyel TM (2013) Health risk assessment of pesticide residues via dietary intake of market vegetables from Dhaka. Bangladesh Foods 2(1):64-75

13. Hu Y, Chiu Y-H, Hauser R, Chavarro J, Sun Q (2016) Overall and class-specific scores of pesticide residues from fruits and vegetables as a tool to rank intake of pesticide residues in United States: a validation study. Environment international 92:294-300

14. Meenambigai C, Bhuvaneswari K, Mohan K, Sangavi R (2017) Pesticides usage pattern of okra, Abelmoschus esculentus (L) Moench in Tamil Nadu. Journal of Entomology Zoology Studies 5(6):1760-1765

15. Mishra P, Singh M (1996) Chemical control of insect pests of Okra in the Tarai region Uttar Pradesh. Indian journal of entomology 58(3):218-221

16. Pandipperuma PANP, Niranjana RF, Senevirathne D, Guruge KPGT (2020) Pesticide residue analysis in Okra (abelmoschus esculentus L.) and brinjal (solanum melongena L.) in the selected areas in Batticaloa district, Sri Lanka. AGRIEAST: Journal of Agricultural Sciences, 14(1), pp.36-43

17. Randhawa MA, Abid QUZ, Anjum FM, Chaudhary AS, Sajid MW, Khalil AA (2016) ORGANO-CHLORINE PESTICIDE RESIDUES IN OKRA AND BRINJAL COLLECTED FROM PERI-URBAN AREAS OF BIG CITIES OF PUNJABPAKISTAN. Pakistan Journal of Agricultural Sciences, 53(2)

18. Randhawa MA, Zaman M, Anjum FM, Asghar A, Sajid MW (2015) Organophosphate pesticide residues in okra and brinjal grown in peri-urban environment of big cities of Punjab. J Chem Soc Pak 37(3):574-578

19. RASFF - Food and Feed Safety Alerts. European Commission (2020) from https://ec.europa.eu/food/food/rasff-food-and-feed-safety-alerts_en 
20. Ratnamma R, Pallavil MS, Pavankumar Mb, Prabhuraj A (2020) Estimation of pesticide residues in okra (Abelmoschus esculentus L.) and risk assessments. J Farm Sci 33(1):105-112

21. Sheikh SA, Nizamani SM, Jamali AA, Panhwar AA, Channa MJ, Mirani BN (2012) Removal of pesticide residues from okra vegetable through traditional processing. J Basic App/ Sci 2012a, 8(1), 79-84

22. Turner JA (2018) A World Compendium The Pesticide Manual: eighteenth edition. British Crop Production Council

23. WHO (2016) Non-communicable diseases risk factors survey-Pakistan. Retrieved from: https://www.who.int/ncds/surveillance/steps/2014_Pakistan_STEPS_Report.pdf

24. You A (2015) Dietary Guidelines for Americans. US Department of Health and Human Services and US Department of Agriculture

\section{Figures}

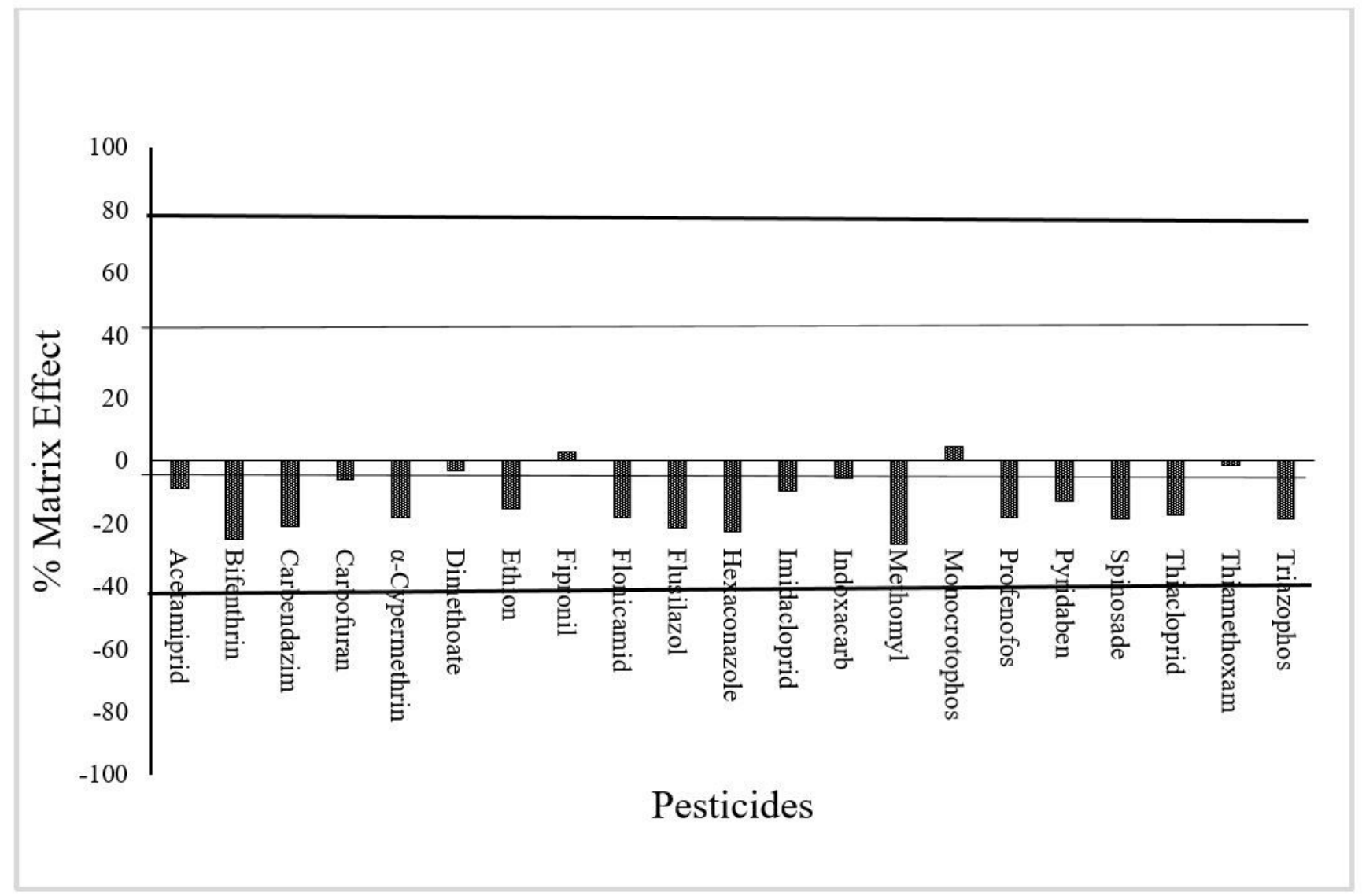

Matrix Effect: Insignificant $< \pm 20 \%$, Medium $\pm 20 \%- \pm 50 \%$, Significant $> \pm 50 \%$

Figure 1

Matrix effect of the selected pesticide in Okra

\section{Supplementary Files}

This is a list of supplementary files associated with this preprint. Click to download.

- SupplementaryInformation.docx 